\title{
PATTERN OF SPINAL CORD INJURY IN THE ELDERLY
}

\author{
By NoRVAL Watson \\ Spinal Injuries Unit, Lodge Moor Hospital, Sheffield
}

PEOPLE are growing older; they are living longer, and the proportion of elderly people in the community is increasing yearly in most countries of the world, and certainly as far as the U.K. is concerned. I decided that it would be appropriate to study the pattern of spinal cord injury in elderly patients admitted to a spinal injury unit serving a large area of central England with a mainly industrial population.

The Unit at Lodge Moor Hospital, Sheffield, serves a population of over five million people, and it is our policy to admit all cases of spinal cord injury offered to us, regardless of age. We have no waiting list, and cases are admitted as soon as they are fit to travel from the casualty department, usually within one to two days of the accident.

I therefore examined the records of all patients with a spinal cord injury who were 60 years or over on the date of the injury, and analysed them to determine whether the pattern of spinal cord injury was different from that of other agegroups and whether there were any particular trends which might help us in the future planning and staffing of spinal injury centres.

During the last 20 years, I955-I974, a total of 99 patients aged 60 years or over had sustained a spinal cord injury, representing about I I per cent of all admissions during that period. The number injured in any single year ranged between I and I I cases, representing between 2 per cent and 28 per cent of all admissions in that year (Table I).

However, when the admissions were analysed in five-year periods, it became immediately evident that the percentage of elderly patients showed a regular increase from 6-9-I2-I 8 per cent in the last quinquennium. If this trend continues, we can expect an ever-increasing proportion of elderly people with spinal cord injury with its associated problems of management and after-care.

When we analysed the levels of injury in the elderly patient group we found a dramatic change from the pattern of injury found in other age-groups. Eightyfour per cent were cervical injuries, an incidence twice that occurring in all agegroups. The numbers of dorsal and lumbar injuries at 8 per cent and 7 per cent respectively were only one-quarter that of all age-groups. This preponderance of quadriplegia means that much more nursing care is required in the elderly groups.

When we considered the sex ratio of the elderly spinal injury cases we found that they were equally divided between male 53 per cent and female 47 per cent (Table II). However, our usual sex ratio in the Unit as a whole is 80 per cent male to 20 per cent female, indicating that there is an incidence more than twice the expected rate as far as old ladies are concerned. This is partly explained by the fact that women live longer than men and there is a higher proportion of women to men in the elderly population. It means, however, that these old ladies have already lost their husbands and may need institutional care afterwards if they are 
TABLE I

\begin{tabular}{|c|c|c|c|c|c|}
\hline & & Incidence & & & \\
\hline & & Incidence & & Levels & \\
\hline & No. & Percentage of all admissions & Cervical & Dorsal & Lumbar \\
\hline $1955-59$ & I4 & 6 & 9 & 2 & 3 \\
\hline I $960-64$ & 19 & 9 & 16 & 2 & I \\
\hline I965-69 & 23 & I2 & 20 & I & 2 \\
\hline I970-74 & 43 & I8 & 39 & 3 & I \\
\hline & $\overline{99}$ & $\overline{\text { II }}$ & $\overline{84}$ & $\overline{8}$ & 7 \\
\hline & & Percentage of all & 43 & 23 & 34 \\
\hline
\end{tabular}

TABLE II

Sex incidence, 1962-1974

$\begin{array}{lccc} & \text { No. } & \% & \text { For all ages } \\ \text { Male } & 4 \mathrm{I} & 53 & 80 \% \\ \text { Female } & 37 & 47 & 20 \%\end{array}$

TABLE III

Mortality in acute phase according to levels and degree of injury

\begin{tabular}{|c|c|c|c|c|c|c|}
\hline & \multicolumn{2}{|c|}{ Cervical (84) } & \multicolumn{2}{|c|}{ Dorsal (8) } & \multicolumn{2}{|c|}{ Lumbar (7) } \\
\hline & $\begin{array}{l}\text { Complete } \\
\text { (II ) }\end{array}$ & $\begin{array}{c}\text { Partial } \\
(73)\end{array}$ & $\begin{array}{c}\text { Complete } \\
(7)\end{array}$ & $\begin{array}{c}\text { Partial } \\
\text { (I) }\end{array}$ & Complete & $\begin{array}{l}\text { Partial } \\
\quad(5)\end{array}$ \\
\hline Surviv & 2 & 56 & 6 & I & I & 5 \\
\hline Died & 9 & I7 & I & - & I & - \\
\hline
\end{tabular}

living alone. They may occupy an acute bed for quite long periods while waiting for a long-stay bed in a geriatric hospital (Table III).

When we studied the level and degree of spinal cord injury, and in particular the prognosis in the acute phase of the injury, we recognised a fairly clear-cut pattern. The mortality in the acute phase was 80 per cent in elderly quadriplegics who had complete lesions, but only 23 per cent in quadriplegics who were incomplete. The mortality rate in paraplegics with a dorsal or lumbar injury was only I3 per cent.

With regard to deaths in the acute phase, these totalled 28, of whom I 5 died within ten days, mainly of respiratory failure. Seven died within six weeks, mainly of pulmonary embolism or heart failure, and six died after six weeks, mainly of causes not attributable to the spinal injury, e.g. cancer, stroke, liver failure, old age. Only one died of sepsis, a late transfer from another hospital. This pattern of death is similar to that of acute deaths at any age-death from respiratory insufficiency in first few days, death from pulmonary embolism in first month, and no deaths attributable to the spinal cord injury in cases who survive the first six weeks treated with a routine paraplegic regime (Table IV). 


\section{TABLE IV}

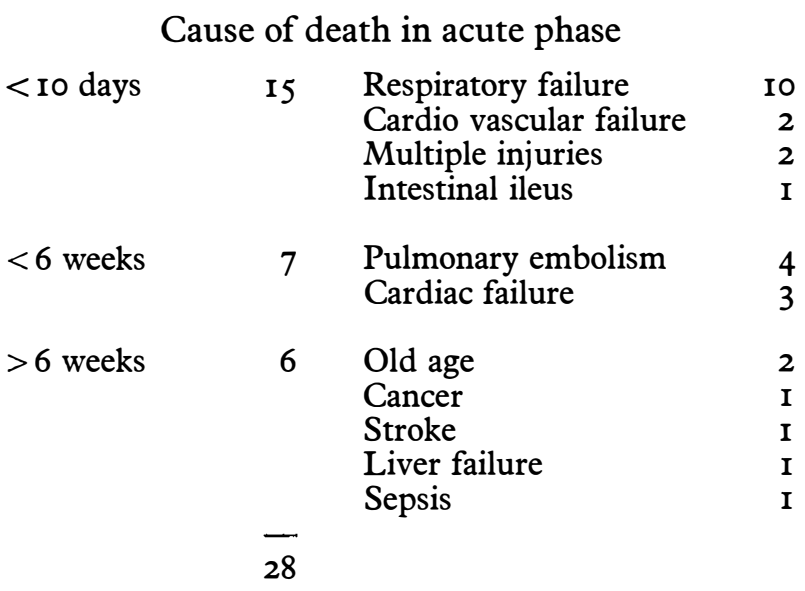

\section{TABle V}

\begin{tabular}{lccc}
\multicolumn{4}{c}{ Prognosis for survivors of acute phase } \\
& Home & Geriatric & Total \\
Alive & 26 & 6 & $32(45 \%)$ \\
Dead & 26 & 13 & $39(55 \%)$ \\
Total & -52 & -19 & 71
\end{tabular}

Seventy-one elderly people with spinal cord injury survived the initial period of hospital treatment and were able to be discharged home or transferred to institutional care (Table V). Fifty-two were able to go home, while I9 had to be transferred to institutional care. The reason for transfer to institutional care was that there was no relative available to care for the patient either in the patient's own home or in the relative's home in the cases in which we considered that the patient was unable to manage alone. They tended, of course, to be the more elderly and more handicapped of our patients, and it is not surprising that they fared worse than the patients who were able to return to their own homes or a relative's home.

Of the 52 who went home, half have survived for varying periods up to 13 years, while of the I9 who went to long-stay hospitals, only one-third have survived and none more than five years (Table VI).

A study of the 7I people who survived the acute phase indicates that 55 per cent have died and 45 per cent are still alive. Of the cases who died after leaving hospital, half died within two years and one-third survived over five years, a few even more than ten years.

The cause of death in those elderly patients who survived the acute phase and died at home or in long-stay hospitals was reported as due to bronchopneumonia in old age in 80 per cent of death certificates, with a small number due to malignancy $7 \frac{1}{2}$ per cent, while only $12 \frac{1}{2}$ per cent were attributable to the spinal cord injury (Table VII). 
TABLE VI

\begin{tabular}{|c|c|c|c|c|c|}
\hline \multicolumn{6}{|c|}{ Survival periods } \\
\hline & $<2$ years & $2-5$ years & 5-10 years & Over Io years & Total \\
\hline Alive & 7 & I4 & 4 & 7 & 32 \\
\hline Deaths & I8 & 9 & 8 & 4 & 39 \\
\hline
\end{tabular}

TABLE VII

Cause of late death

$\begin{array}{lrc}\begin{array}{l}\text { Old age } \\ \text { Respiratory } \\ \text { Cardiac }\end{array} & 20 & \\ \text { Malignancy } & 2 & 31(80 \%) \\ \text { Renal } & 3 & 3\left(7 \frac{1}{2} \%\right) \\ \text { Sores } & 4 & 5\left(12 \frac{1}{2} \%\right) \\ & \text { I } & \text { attributable } \\ & \text { 39 } & \end{array}$

TABLE VIII

Cause of accident

Home 54

Road traffic accident $\quad 28$

Work 15

Sport 2

99

An enquiry into the circumstances of the accidents sustained by these elderly people revealed that the majority, 54 per cent, were caused by accidents in the home. Over a quarter were involved in road traffic acicdents, 28 per cent, and a smaller number, I5 per cent, occurred at work. The two sporting injuries occurred while rock climbing and horse riding (Table VIII).

The most common circumstance is that in which an elderly person with a spondylotic cervical spine gets out of bed at night to go to the toilet and falls downstairs in the dark, sustaining a hyperextension type of injury to the neck causing a partial quadriplegia.

Our oldest patient was an old lady of 87 years who fell downstairs at 4 a.m. while on holiday at her son's house. She sustained a fracture dislocation of the cervical spine with a complete dislocation at level C.V.5 on C.V.6 with fracture of spinous processes C.V.4 and 5. Neurologically she had an incomplete quadriplegia, with a weak right arm and completely paralysed left arm, and fair power in both legs. The dislocation was reduced by skull traction, recovery in the left arm started in the first week and by the tenth week all muscle groups had recovered to power four. She had a catheter for nine weeks, then regained fair control of her bladder with some urgency. She was discharged to an old persons' home four months after the injury, walking with two sticks independently. Despite the fact that she was our oldest patient with the most severe degree of bony injury, she made a quite exceptional recovery, and she proved that age itself is no barrier to a successful rehabilitation. She fully vindicated our policy to admit all cases of spinal injury for treatment regardless of age. 


\section{SUMMARY}

A study was made of the pattern of spinal cord injury in the elderly who are forming an ever-increasing proportion of our population.

It was noted that the elderly patients had a higher incidence of cervical injuries than other age-groups with a much lower incidence of dorsal and lumbar injuries.

The mortality rate in complete cervical injuries was very high but in incomplete cervical injuries and those at a lower level the majority survived the acute phase.

The cause of death in the acute phase was similar to that of other age-groups. The majority of survivors were able to be discharged to their own homes to the care of relatives and they fared better than those who had to be transferred to long term geriatric hospitals.

Most of the late deaths occurred within five years of discharge from hospital but a few survived over ten years.

The causes of the accidents were mostly falls at home and less frequently road traffic accidents.

\section{RÉSUMÉ}

Une étude a été faite sur le schèma que presente la lesion de la moëlle èpinière chez les personnes agées, qui forment une part de plus en plus importante de notre population.

On remarqua que les malades agés avaient plus de lesions cervicales que d'autres groupes d'âge et moins de lesions dorsales et lombaires.

Le taux de mortalité pour les lesions cervicales totales était tres haut mais dans le cas des lesions cervicales partielles et de celles situées à un niveau plus bas, la majorite survivait à la phase critique.

La cause de la mort pendant la phase critique était la même que celle des autres groupes d'âge. On puit rendre la majorité des survivants à leurs maisons et au sóin de leurs parents et ils se porterent mieux que ceux qui avaient du être transferré dans des hospices speciaux pour les personnes agées.

La plupart des morts tardives advint dans les 5 années suivant la sortie de l'hôpital mais quelques uns ne moururent que plus de dix ans après.

Les accidents ètaient surtout causés par des chutes dans leur domicile et moins fréquemment par des accidents de circulation.

\section{ZUSAMMENFASSUNG}

Es wurde eine Studie über das Auftreten der Rückenmarkverletzungen bei älteren Menschen unternommen, deren Anteil an der Gesamtbevölkerung ständig wächst.

Es wurde festgestellt, da B bei älteren Patienten das Vorkommen von zervikalen Verletzungen höher war, als bei anderen Altersgruppen mit viel geringerem Auftreten der dorsalen und lumbalen Schäden.

Die Sterblichkeitsrate war bei kompletten zervikalen Schäden sehr hoch, aber bei inkompletten und geringeren zervikalen Schäden überlebte die Mehrzahl die akute Phase.

Die Todesursache in der akuten Phase war ähnlich der der anderen Altersgruppen.

Die Mehrzahl der Überlebenden konnte aus dem Krankenhaus entlassen und zu Hause gepflegt werden. Sie erholten sich besser als die Patienten, die für lange Zeit in ein Pflegeheim verlegt werden mußten.

Die meisten der am längsten Überlebenden starben innerhalb der ersten fünf Jahre nach der Entlassung aus dem Krankenhaus, aber einige überlebten über zehn Jahre.

Die Ursachen der Verletzungen waren meistens Stürze im Haushalt und weniger häufig Straßenverkehrxunfälle. 